\title{
WestVirginiaUniversity.
}

Department of Economics

Working Paper Series

\section{Teaching the Economic Way of Thinking Through Op-eds}

Joshua Hall and Marta Podemska-Mikluch

Working Paper No. 15-10

This paper can be found at the College of Business and Economics

Working Paper Series homepage: 


\title{
Teaching the Economic Way of Thinking Through Op-eds
}

\author{
Joshua C. Hall ${ }^{*}$ \\ Department of Economics \\ West Virginia University \\ Morgantown, WV \\ joshua.c.hall@gmail.com \\ Marta Podemska-Mikluch \\ Department of Economics and Management \\ Gustavus Adolphus College \\ St. Peter, MN \\ mpodemsk@gustavus.edu
}

\begin{abstract}
There are many goals an instructor may wish to accomplish in a course on economic principles. For us one goal should be the education of a generation of sensible and active members of civil society. This is an ambitious goal: it requires that students internalize the economic way of thinking and learn to exercise active citizenry. After experimenting with a variety of methods, we have concluded that requiring students to write an op-ed is the most conducive to the development of the economic way of thinking. Here we share what we have learned in the process, hoping that the pedagogical capability of writing an op-ed will encourage others to adopt the assignment into their classrooms.
\end{abstract}

Keywords: Engagement, Op-ed, Principles of Economics, Writing.

JEL Codes: A11, A13, A22, D01, D7, D72.

\footnotetext{
* Corresponding author. The authors would like to thank Tony Carilli for organizing the panel discussion titled "Most of My Students Are Going Pro in Something Other than Economics: Teaching the Citizen Economists" at the 2012 SDAE meetings and encouraging us to write up our thoughts into this paper. Joshua Hall would like to thank the Center for Free Enterprise at West Virginia University for general research support.
} 


\section{Teaching the Economic Way of Thinking Through Op-eds}

\section{Introduction}

Those of us who teach principles of economics have a single shot at exposing students to the economic way of thinking. From all the students taking principles of economics, only a few will choose to take another economics course, even fewer will choose to major in economics, and a trivial number will go on to study economics at a graduate level. ${ }^{1}$ Given the non-repeated nature of the interaction, such a unique opportunity must be afforded due consideration (Krugman 1993). That one semester must be used in a manner that maximizes the likelihood of generating sensible citizenry - that is, citizens capable of recognizing the constraints imposed by scarcity and the implications of dispersed knowledge. Instead of feeding the students with the proverbial fish, we need to use the little time we have to equip them with the analytical skills that will serve them as citizens; to help them adopt the economic way of thinking.

There is a long line of literature in economics on the excessive use of lecturing, or “chalk and talk” by economic faculty (Becker and Watts 1996; Becker 1997; Becker and Watts 2001; Watts and Becker 2008). This has led to a number of papers and other publications that discuss going beyond lecturing and instead getting students to engage in active learning (Gail Mitchell Hoyt and McGoldrick 2012). Salemi (2002) provides a strong argument for active learning as well as a thorough overview of the literature on

\footnotetext{
${ }^{1}$ Bosshardt and Watts (2008) report, using data from the Baccalaureate and Beyond data set from the National Center for Education Statistics, that the average number of economics courses completed for credit in the Baccalaureate and Beyond sample was 1.51. Nearly sixty percent of students in the sample completed at least one economics course.
} 
active learning. Economics educators have suggested a variety of methods to get students to engage in active learning, including: classroom exercises utilizing internet research (Simkins 1999); online assignments and discussion boards (Vachris 1999), watching and discussing clips from popular television shows (Hall 2005; Gillis and Hall 2010; Mateer et al. 2011), watching portions of movies with economic based content (Mateer and Stephenson 2011), listening to music with economic themes (Hall and Lawson 2008; Lawson et al. 2008), and classroom experiments (Hunsader et al. 2011; Nikolaev 2014). ${ }^{2}$

Writing is one of the more traditional ways to get students to "do" economics. However, many believe that grading writing is too time consuming to be assigned in large classes, typically found at state universities. However, authors increasingly argue that writing assignments are plausible beyond the classrooms of liberal arts colleges, due to technological advances (Mahalingam 2013) and adoption of peer-review ("Using Cooperative Peer Editing to Improve Writing Assignments in Economics” 2015). This is comforting since there is a body of literature on writing in economics (Cohen and Spencer 1993; Simpson and Carroll 1999; Greenlaw 2003), which largely finds that writing encourages student engagement, promotes absorption of course content (Crowe and Youga 1986), and develops critical thinking (Wight 1999). Moreover, there is a growing literature on engaging students in practical, real-world writing tasks, as exemplified by research on using blogs to spark engagement, even in large classrooms (Farmer et al. 2008; Cameron 2012; Cameron and Piercy 2013)

We developed the op-ed while teaching principles of economics in a small liberal arts college. After experimenting with a variety of different assignments, we have learned

\footnotetext{
2 Harmon and Lambrinos (2012) provide a large number of active learning exercises for the principles classroom.
} 
that requiring students to write an op-ed is a great way of motivating them to internalize the economic way of thinking. This is evidenced by the feedback we have received from the students (most informative comments are cited in the Appendix 2). In the remainder of this article we discuss our op-ed approach and the reasons why we believe assigning it has been an effective use of classroom, student, and instructor time. As a preview, however, there are four major reasons behind the effectiveness of our approach. First, opeds are short and therefore easily manageable for the instructor who wants to assign writing in her classroom. Second, given that students are free to work on any topic of their choosing, an op-ed assignment takes advantage of the passions and hobbies students had prior to taking the course. Third, writing an op-ed provides students with an opportunity to experience the usefulness of the economic way of thinking firsthand. Fourth, writing an op-ed prepares students to be active members of civil society.

Our paper proceeds as follows. In Section 2, we discuss the basics of the assignment itself as well as some practical implications of the assignment for the instructor, although some discussion of the assignment will occur later in the paper (a full version of the assignment is available in the Appendix 1). We discuss the raison d'être for using our op-ed assignment in introductory classes or courses geared primarily at nonmajors in Section 3, while Section 4 concludes.

\section{The Assignment}

One reason to assign op-eds as opposed to other writing projects is their manageability. Op-eds are short: we usually ask that students produce a piece of about 550-750 words. 
The shortness of the project allows students to experiment with a variety of ideas at a low cost. Should a student hit a wall or for some other reason realize they want to change the topic, it is easy to start on something new and have it completed within a short time. In contrast, such change is usually impossible when working on a longer project as the approaching deadline usually means that sticking with the original idea is the only way to get the work done on time. The shortness of the assignments gives students the opportunity to try arguments on at a low cost, which in practice has meant that they rarely find it difficult to start. In our experience, this is stark contrast with longer assignments, which students often find very intimidating. Moreover, the shortness of the op-ed allows the instructor to play an active role in guiding each student's thoughts. It is much easier to provide numerous students brief input on an assignment that has 500 words as opposed to five or ten pages.

More often than not, one or two semesters of college are not enough to prepare a student for writing a well-thought out research paper. In our experience, assigning a project of substantial length in an introductory course causes anxiety and frustration among the students (and professors). In contrast, the shortness of the op-ed, combined with clear real-world examples, makes for a non-threatening assignment. This is further complemented by the fact that many op-eds are written by non-journalists. As we explain to students in the description of the assignment, writing an op-ed requires no prior knowledge of journalism (or economics!) and can be easily done by someone with little writing experience: ${ }^{3}$

Your task is to write an op-ed applying the economic way of thinking to a public policy issue. Op-ed is a newspaper article that expresses the opinions of a writer

\footnotetext{
${ }^{3}$ For the full assignment, see Appendix 1.
} 
who is usually unaffiliated with the newspaper's editorial board. Op-eds give an informed viewpoint on a topic that is of interest to the general public.

We further contribute to the non-threatening nature of the assignment by presenting it to students about four weeks into the semester. At that point students already know enough basic economics to start outlining their argument. But it is not unusual for students to feel uneasy about arguing from the economic perspective just four weeks after their first encounter with economic reasoning. This uneasiness can be turned into fertile ground for the growth of economic ideas; this is the perfect time to expose students to the ubiquitous abuse of economic reasoning. Once students realize how public figures discount or ignore economic principles, they begin to perceive themselves as sufficiently prepared to tackle the op-ed.

To facilitate the exposure to economic fallacies, we usually initiate a discussion of a policy that is currently in the news. We shortly review the main aspects of the public discourse as portrayed by the media and then ask students which economic principles are broken by those in favor of the policy and which principles are broken by the opponents. In their answers, students usually talk about opportunity cost, unintended consequences, and the power of incentives. This short exercise gives students an opportunity to realize how one could use any single one of economic principles to write an endless number of op-eds by pointing out popular fallacies.

While this short demonstration is centered on the issues of public policy, we allow students complete flexibility in choosing the topic. As we write in the assignment:

The topic and opinion in the article are entirely up to you. Please feel free to run your idea by me before you start writing, but don't feel required to do so. 
Students can write about a topic discussed in class or about something completely unrelated to class material. In the spring of 2013, five of 26 students in one of our principles classes used the op-ed as an opportunity to discuss the proposal to increase the federal minimum wage made by President Obama in his 2013 Address on the State of the Union. Other students chose topics that were never even mentioned in class. One student wrote a very interesting piece about New York Fashion Week and its coordinating role within the fashion industry. This also has the added advantage of being more interesting to grade. Twenty-five or more op-eds on the same theme might be simpler to grade, but far more boring. We have learned a lot from our students' op-eds over the years and have often used them as a springboard for longer essays and journal articles with the students. Some examples include Helling et al. (2008) and Kotkin et al. (2010).

While we give students flexibility in regard to the topic of the op-ed and their viewpoint, we ask that they produce an informative and well-reasoned piece. We specify in the assignment, that they are free to argue for any position, as long as their arguments are based on evidence:

While op-eds are written to express authors' opinion, they also contain information. This information could be facts, statistics, anecdotes, or summaries of academic research.

This condition encourages students to do some elementary research, which often causes them to dramatically change their perspective. For example, one student who was very much in favor of policies promoting renewable energy changed her mind after researching the topic and ended up writing a piece arguing against ethanol subsidies. 
This being said, it is also important to prevent the assignment from becoming a quasiresearch paper or an outlet for newly acquired economic jargon. This is why we emphasize that the purpose of the assignment is to convince the readers to consider the conclusion of the economic way of thinking:

Remember: your goal is to convince! Utilize any information you think will persuade the readers to consider the economic perspective.

This objective also serves our paramount goal of having students adopt the economic way of thinking for life. Being able to successfully communicate economic principles is an important test of one's mastery of the subject. We make sure that students understand they are supposed to combine evidence and economic reasoning in an informative and easily digestible manner:

The best op-eds provide readers with new information or insight on a topic. Telling someone "People who don't recycle are selfish" is not informative and, ultimately not compelling. Telling the reader "Recycling reduces the amount of trash going into local landfills by $\mathrm{X}$ tons a year" is informative.

To further clarify our expectations, we supplement the description of the assignment with examples. We usually provide students with copies of a number of different op-eds, some from local papers as well as national newspapers such as the Wall Street Journal and the New York Times. In addition, showing the class some published op-eds from previous classes is helpful, since it shows the class that similarly situated students were able to write good op-eds. To strengthen the point that an op-ed is a method of inspiring a public discourse, one of us recently encouraged her students to read a very controversial, viral 
op-ed published in the Daily Princetonian (Patton 2013). Students were also expected to follow the on-line chain of endless responses elicited by this op-ed.

Finally, we incentivize the students to submit their op-ed for publication by offering them extra-credit:

After turning in your final draft I encourage you to submit your op-ed for publication somewhere (the Beloit College Roundtable would be an obvious choice). If your op-ed is accepted for publication, you will receive five percentage points of extra credit plus full credit on the assignment. Meeting the market test is what matters!

This has several purposes. First and foremost, it reminds the students that what matters most is not the grade they get in the course, but rather how what they do in the classroom influences their ability to engage the world around them. Second, it makes clear that economics is not just a game to be played by clever people but rather insights to be applied to the world around us to improve things we care about. (Remember, presumably they are writing on a topic about which they are passionate.) Third, it signals humility in grading, which we feel it is important for faculty to do, especially in an environment where you know every student on a first-name basis. Fourth, for students who are interested in a career in journalism or public policy, it helps them to start building a portfolio. Lastly, for faculty, some op-eds might be publishable with some additional work along with the faculty member and provide possible publication opportunities for students that might count as publishing or service for tenure and promotion, depending upon the institution. ${ }^{4}$

There are many ways to incorporate this assignment in a classroom and there are also many ways to grade it. We leave these choices open for the instructors to determine

\footnotetext{
${ }^{4}$ As further example of this type of co-authored work with students that started as class op-eds, see Abraham et al. (2009).
} 
based on the knowledge of their institutional setting and the students. In our respective cases, after some experimentation, we settled on weighting the assignment at ten percent of final grade, with the rest of the grade being determined by typical principles of economics problem sets and tests. As already mentioned, we also awarded students' additional points for passing the market test. If the op-ed gets published in a local newspaper or in an on-line news outlet, the student receives extra credit worth five percent of the final grade, plus full credit on the assignment.

\section{$3 \quad$ Promoting Economics through Product Bundling}

If you reflect back to your first few weeks of teaching economics, you will likely recall a surprising sense of disappointment triggered by the discovery that your students weren't nearly as excited about economics as you or your friends from graduate school. While we all like to think that our excitement and passion are contagious, inspiring students to fall in love with the economic way of thinking is not easy and definitely doesn't happen overnight. Students who take principles of economics usually do so because the course is a requirement. For that reason, and because of the stereotypes perpetuated by the media and pop-culture, an economics instructor begins every semester facing a group that has a very low expectation for the following weeks. And, as is usually the case with selffulfilling prophecies, those low expectations are quickly reinforced. In the early weeks of the semester, some of the more forthcoming students may share their confusion about the jargon and the endless graphs that appear to have no real world significance. But within a couple of weeks even they join the ranks of bored and disengaged. Soon thereafter, the 
students' attention is reduced to getting through the tests, the instructors concentrate on surviving the piles of grading to be done, and all are united in counting the days towards the end of the semester.

While not all of us can relate to this bleak visualization, we all constantly seek ways to increase student engagement, as it is a widely recognized prerequisite for intellectual growth (Barkley 2009). What can we do? Shall we sign up for a course on motivational speaking or better yet study training or hallucination techniques? Luckily, less desperate measures are available. The solution has been around for centuries. Most of us have studied it, either directly in the history of economic or political thought courses or indirectly in the study of rational ignorance. Here it is again: the bundling of ideas! In order to have our students adopt the economic way of thinking, we need to tie it to issues that already excite them.

While most of the students have no interest or passion for economics, they are most likely passionate about something else. Given the universality of the economic way of thinking, that passion can easily be expanded to include economic ideas. All we need to do is give the students an opportunity to experience the unparalleled usefulness and applicability of the economic way of thinking. In doing so, we follow Machiavelli's timeless advice: we become a lion and a fox (Machiavelli 1532).

For the bundling of ideas to be effective, we need to encourage students to pick any topic they want. Students must have complete freedom in terms of what they would like to ponder; the only suggestion we make is that they work on something that has already interested them that has an economics component. So far, we had students write about conventional economic topics such as minimum wage laws, agricultural subsidies, 
and educational vouchers, in addition to unconventional topics such as fashion, abortion, recycling, and stadium subsidies. The great thing about the economic way of thinking is it applies to any topic in which a student might be interested. In nearly all of the cases, students shared their surprise or even astonishment at how much their understanding has changed during the process of developing the op-ed.

What is great, especially at a school like Beloit College where students are often initially skeptical of markets, the freedom to choose their own topic allows them to harness the power of the economic way of thinking to better understand something that they care about very deeply. One of us used an earlier version of this assignment in his first principles of economics class at Beloit College. The students wrote on global warming, fair trade, the tradeoffs teenagers face while working, the effect of high marginal tax rates, congestion pricing, grain subsidies, and many more widely diverse topics. By building in feedback into assignments, students were able to see that it was not about the conclusion they drew, but rather about the path they took to reach that conclusion. What assumptions were made regarding individual behavior? Is the analysis dealing with the short-run or the long-run? For many students who were initially really critical of economics, having the opportunity to apply economics in support of something they care about was the start to getting them to think like an economist through practice. If our goal is for students to internalize the economic way of thinking, then we need to help them develop a habit of turning to economics each time they are puzzled by a social phenomenon. Charles Duhigg, the author of the bestselling The Power of Habit, argues that habits are established through a reward loop. Reward loop has three elements: cue, routine, and reward (Duhigg 2012). The reward serves to further reinforce the routine 
response to the cue. From this perspective, our task of turning students into sensible citizens will be accomplished once they establish a habit of turning to economics for clarity.

\section{Concluding Thoughts}

Our goal was to present the pedagogical potential of requiring students to write an op-ed in introductory courses on economic principles. In our experience, we have learned that op-eds serve three major purposes: they are an excellent way of engaging the students, they encourage students to adopt the economic way of thinking for life, and they inspire students to become active advocates of economic reasoning. We hope that others will build on our experience and will consider adopting this type of assignment into their classrooms. Even the most modest contribution to the popularization of economic reasoning would vindicate our efforts.

The op-ed assignment is a very effective starting point for establishing a habit loop where social puzzles are cues, economic reasoning is a routine response, and clarity is a reward. Writing on op-ed allows students to quickly discover the usefulness and applicability of economic reasoning. The ability to pick any topic of their choosing allows students to experience firsthand the usefulness of the economic way of thinking. While working on the project, they discover how economic tools elucidate their reasoning about issues they already find important. The routine response is reinforced by the reward in the form of newly found clarity and insight. This reward in turn motivates them to further strengthen their intellectual toolkit. As their skills improve, they are likely 
to apply the economic way of thinking to other issues. And if reasoning is anything like riding a bike, this ability will stay with them for the rest of their lives. 


\section{References}

Abraham, Nick, Scott Beaulier, and Joshua Hall. 2009. “Government Shouldn’t Sell Short-Selling Shor.” Macon Telegraph, January 17.

Barkley, Elizabeth F. 2009. Student Engagement Techniques: A Handbook for College Faculty. 1st ed. Jossey-Bass.

Becker, William E. 1997. “Teaching Economics to Undergraduates.” Journal of Economic Literature 35 (3): 1347-73.

Becker, William E., and Michael Watts. 1996. "Chalk and Talk: A National Survey on Teaching Undergraduate Economics.” American Economic Review 86 (2): 44853.

— 2001. "Teaching Economics at the Start of the 21st Century: Still Chalk-andTalk.” American Economic Review 91 (2): 446-51.

Bosshardt, William, and Michael Watts. 2008. “Undergraduate Students’ Coursework in Economics.” Journal of Economic Education 39 (2): 198-205.

Cameron, M. 2012. “'Economics with Training Wheels”: Using Blogs in Teaching and Assessing Introductory Economics.” Journal of Economic Education 43 (4): 397407. doi:10.1080/00220485.2012.714316.

Cameron, M., and G. Piercy. 2013. “Adapting Assessment and Classroom Practices to Foster Student Engagement.” In EDULEARN13 Proceedings, edited by L. Gomez Chova and I. Candel Torres, 3903-12. Barcelona. http://library.iated.org/view/CAMERON2013ADA.

Cohen, Avi J., and John Spencer. 1993. "Using Writing across the Curriculum in Economics: Is Taking the Plunge Worth It?” Journal of Economic Education, 219-30.

Crowe, Douglas, and Janet Youga. 1986. "Using Writing as a Tool for Learning Economics.” The Journal of Economic Education 17 (3): 218-22.

Deloach, Stephen B., and Steven A. Greenlaw. 2005. "Do Electronic Discussions Create Critical Thinking Spillovers?” Contemporary Economic Policy 23 (1): 149-63. doi:10.1093/cep/byi012.

Duhigg, Charles. 2012. The Power of Habit. Why We Do What We Do in Life and Business. New York: Random House.

Dynan, Linda, and Tom Cate. 2009. “The Impact of Writing Assignments on Student Learning: Should Writing Assignments Be Structured or Unstructured?” International Review of Economic Education 8 (1): 64-86.

Farmer, Brett, Audrey Yue, and Claire Brooks. 2008. "Using Blogging for Higher Order Learning in Large Cohort University Teaching: A Case Study.” Australasian Journal of Educational Technology 24 (2). http://ascilite.org.au/ajet/submission/index.php/AJET/article/view/1215. 
Gillis, Mark T., and Joshua Hall. 2010. "Using The Simpsons to Improve Economic Instruction through Policy Analysis.” American Economist 55 (1): 84.

Greenlaw, Steven A. 2003. "Using Writing to Enhance Student Learning in Undergraduate Economics.” International Review of Economic Education 1 (1): 61-70.

Hall, Joshua. 2005. "Homer Economicus: Using The Simpsons to Teach Economics.” Journal of Private Enterprise 20 (2): 165-76.

Hall, Joshua, and Robert A. Lawson. 2008. “Using Music to Teach Microeconomics.” Perspectives in Economic Education Research 4 (1): 23-36.

Hansen, W. Lee. 1998. “Integrating the Practice of Writing into Economics Instruction.” Teaching Economics to Undergraduates: Alternatives to Chalk and Talk. Cheltenham, UK: Edward Elgar Publishing Limited, 79-118.

Harmon, Oskar R., and James Lambrinos. 2012. "Active-Learning Exercises for Principles of Economics Courses.” The Journal of Economic Education 43 (2): 221-221.

Helling, Madeline, Scott Beaulier, and Joshua Hall. 2008. "High Cotton: Why the United States Should No Longer Provide Agricultural Subsidies to Cotton Farmers.” Economic Affairs 28 (2): 65-66.

Hoyt, Gail Mitchell, and KimMarie McGoldrick. 2012. International Handbook on Teaching and Learning Economics. Edward Elgar Publishing.

Hunsader, Kenneth J., David T. Mitchell, and Scott Parker. 2011. “A Futures Trading Experiment: An Active Classroom Approach to Learning." Journal of Economics and Finance Education 10 (1): 19.

Kotkin, Rachel, Joshua Hall, and Scott Beaulier. 2010. “The Virtue of Business: How Markets Encourage Ethical Behavior.” Journal of Markets and Morality 13 (1): 45-58.

Krugman, Paul R. 1993. “What Do Undergrads Need to Know about Trade?” American Economic Review 83 (2): 23-26.

Lawson, Robert A., Joshua Hall, and G. Dirk Mateer. 2008. "From Abba to Zeppelin, Led: Using Music to Teach Economics.” Journal of Economic Education 39 (1): 107-107.

Machiavelli, Niccolo. 1532. The Prince. Edited and translated by Robert M. Adams. New York: Norton, 1992.: Norton Critical Editions.

Mahalingam, Brinda. 2013. "Revival of Essay Writing in Economics.” International Journal of Pluralism and Economics Education 4 (2): 183-91.

Mateer, G. Dirk, Linda S. Ghent, and Misty Stone. 2011. “TV for Economics.” The Journal of Economic Education 42 (2): 207-207.

Mateer, G. Dirk, and E. Frank Stephenson. 2011. "Using Film Clips to Teach Public Choice Economics.” Journal of Economics and Finance Education 10 (1): 28. 
Nikolaev, Boris. 2013. "Using Experiments and Media to Introduce Game Theory into the Principles Classroom.” Journal of Private Enterprise Forthcoming.

Patton, Susan A. 2013. "Letter to the Editor: Advice for the Young Women of Princeton: The Daughters I Never Had.” The Daily Princetonian.

Perry-Sizemore, Elizabeth, and Steven A. Greenlaw. 2012. "Writing for Learning in Economics.” In International Handbook on Teaching and Learning Economics, edited by Gail M. Hoyt and KimMarie McGoldrick, 137-46.

Salemi, Michael K. 2002. “An Illustrated Case for Active Learning.” Southern Economic Journal, 721-31.

Simkins, Scott Paul. 1999. "Promoting Active-Student Learning Using the World Wide Web in Economics Courses.” Journal of Economic Education 30 (3): 278-87.

Simpson, Murray S., and Shireen E. Carroll. 1999. “Assignments for a Writing-Intensive Economics Course.” The Journal of Economic Education 30 (4): 402-10.

“Using Cooperative Peer Editing to Improve Writing Assignments in Economics.” 2015. Examples. Accessed April 26. http://serc.carleton.edu/econ/cooperative/examples/61502.html.

Vachris, Michelle Albert. 1999. "Teaching Principles of Economics without 'Chalk and Talk': The Experience of CNU Online.” Journal of Economic Education 30 (3): 292-307.

Van Horn, Robert, and Monica Van Horn. 2013. "What Would Adam Smith Have on His iPod? Uses of Music in Teaching the History of Economic Thought.” The Journal of Economic Education 44 (1): 64-73. doi:10.1080/00220485.2013.744619.

Watts, Michael, and William E. Becker. 2008. “A Little More than Chalk and Talk: Results from a Third National Survey of Teaching Methods in Undergraduate Economics Courses.” Journal of Economic Education 39 (3): 273-86.

Wight, Jonathan B. 1999. "Using Electronic Data Tools in Writing Assignments.” Journal of Economic Education 30 (1): 21-27. 
Length: 550-750 words

Final version due date: beginning of class on April $18^{\text {th }} 2013^{1}$

Submission format: hard copy

Your task is to write an op-ed applying the economic way of thinking to a public policy issue. Op-ed is a newspaper article that expresses the opinions of a writer who is usually unaffiliated with the newspaper's editorial board. Op-eds give an informed viewpoint on a topic that is of interest to the general public. The topic and opinion in the article are entirely up to you. Please feel free to run your idea by me before you start writing, but don’t feel required to do so.

While op-eds are written to express authors' opinion, they also contain information. This information could be facts, statistics, anecdotes, or summaries of academic research. Remember: your goal is to convince! Utilize any information you think will persuade the readers to consider the economic perspective.

If you are not familiar with op-eds a good place to start is the opinion page of your hometown newspaper, Wall Street Journal or the New York Times. Get a flavor of what op-eds are about and if you have trouble identifying a topic or backing up your opinion, please come to see me for assistance.

The best op-eds provide readers with new information or insight on a topic. Telling someone "People who don't recycle are selfish" is not informative and, ultimately not compelling. Telling the reader "Recycling reduces the amount of trash going into local landfills by $\mathrm{X}$ tons a year" is informative.

Your grade will be determined by your ability to analyze the material from the economic perspective as well as by the quality of your writing, including spelling, grammar, and style. You're welcome to first submit a draft version (by April $9^{\text {th }}$ ) to which I will respond with comments. You are then free to incorporate my comments for the final version.

After turning in your final draft I encourage you to submit your op-ed for publication somewhere (the Beloit College Roundtable would be an obvious choice. If your op-ed is accepted for publication, you will receive five percentage points of extra credit plus full credit on the assignment. Meeting the market test is what matters!

I expect all students to strictly follow the academic honesty policy, which can be consulted online. Every case of academic dishonesty will result in a score of zero points and will be reported to the dean of students.

${ }^{1}$ As specified on the syllabus, late submissions will be penalized by a twenty percent grade decrease for each day of lateness 
Appendix 2. Student Feedback

There were no specific questions regarding op-eds in our evaluations. Yet, students brought them up when writing about what assignments they found most conducive to learning. The following are direct quotations from former students.

"I really liked and learned from all of the assignments that were given, especially the oped. I would have liked to do more assignments like that b/c it would me apply what I have learned"

To gain additional feedback, we followed up with the students, three months after the class was over. The feedback was overwhelmingly positive. Here are some of the most informative responses:

"I thought that the op-eds were interesting and helped us to think critically about the theory and ideas in economics."

"As far as the op-ed goes, I thought they were a good way of looking at an economists perspective. And they did do a good job at having the student get into that perspective as well.”

"I believe doing the Op-ed was a great idea and definitely something for future classes. It was beneficial in that it tied together current (or semi current) events and explained them with economic terms/reasoning learned in class. Therefore not only could we process events in a more economic viewpoint, which I would say is quite new to us students, but also in that we could fully apply it with our knowledge from the textbook / your lectures, which is a good learning tool.”

"I believe that the op-ed assignment was very helpful in learning the economic way of thinking. The assignment makes us view problems/topics in a more analytical and focused manner. I thought that the op-ed assignment challenged us to utilize the information which we had learned through class and apply it to real world situations. It was also a useful assignment because it forced us to explore and examine some of the currently debated issues/topics of the world today. I recommend assigning op-eds again in the future because they gave students the opportunity to apply the knowledge that they had been learning in class to current issues."

"I think the op-ed assignment was very beneficial to my economic learning. By employing the different ways of economic thinking to a single issue, it forced me to think of explanations from multiple angles. This not only enhanced my understanding of each economic point, but also caused me to think critically about each argument I was making. This assignment also reinforced why social explanations for problems do not always work/apply; sometimes proving something by factual, economic proof can create a solution more quickly and more effectively. I hope you continue to use op-eds in your curriculum so other students are able to learn as much and have as much fun as I did in your class.” 